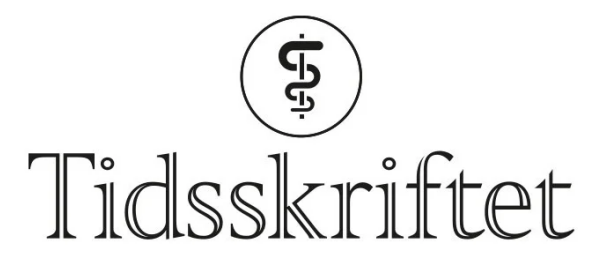

DEN NORSKE LEGEFORENING

\title{
Birger Løvland
}

\author{
MINNEORD
}

KARL O. NAKKEN

VIDAR SKAUG

KJETIL K. MELBY

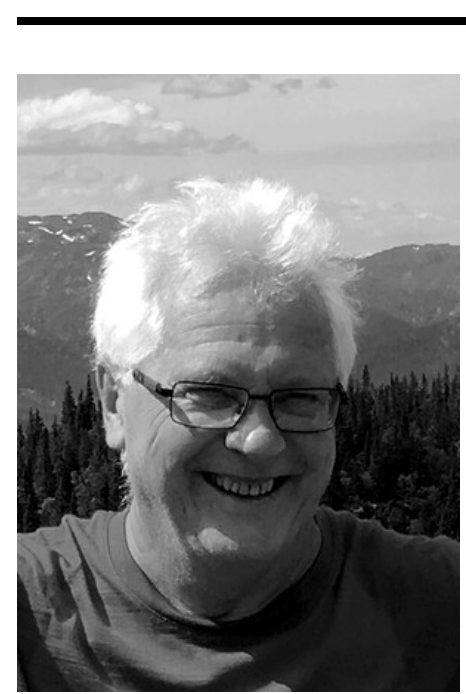

Vår nære venn og kollega Birger Løvland døde brått og uventet etter en hjerteoperasjon 4. mai 2021, snaut 75 år gammel. Det er vanskelig å fatte og akseptere at Birger er borte for alltid.

I studietiden i Oslo for rundt 50 år siden lærte vi snart å sette stor pris på denne rause, blide og energiske sørlendingen. Han ervervet seg raskt så omfattende anatomikunnskaper at han ble utpekt som prosektor minor for kullet under oss. Senere fungerte han i mange år som sensor ved anatomieksamen ved Universitet i Oslo.

Som en av de dyktigste på vårt studentkull spådde vi ham en lysende akademisk karriere. Men Birger ønsket å bruke sine rike evner som lege i førstelinjetjenesten. I 47 år var han allmennpraktiserende lege på Ski, men hadde planer om å pensjonere seg fra sommeren. Med blikk for alle elementer i helsebegrepet, det fysiske, psykiske og det sosiale, kom han til å spille en viktig rolle i mange menneskers liv. I Nordre Follo er han blitt et begrep. 
I studietiden traff han sin kjære Hilde Berdal som gikk på kullet under. Dessverre omkom Hilde i en tragisk bilulykke i 1986. Årene som fulgte, ble en tung tid for Birger. Etter hvert traff han imidlertid Anita, som var et lykketreff for ham.

Birger imponerte oss alle med sine brede kunnskaper, ikke bare innen medisin, men også innen geografi, geologi og lokalhistorie. Sammen med Anita forfattet han en rekke turbøker, bl.a. fra Kanariøyene, Azorene, Madeira og Mallorca, men også fra nærområdene i Follomarka og Sørmarka. I lokalavisen hadde de en fast spalte med turforslag. Det er naturligvis vanskelig å måle effekten av slike turbøker og artikler, men at de har hatt en helsefremmende effekt for mange mennesker, er vi ikke i tvil om.

På Eidsbugarden har han skrevet sitt navn med gullskrift. Han kjøpte hytte der i 1972, og i 1985 etablerte han hyttemagasinet Eidsbugarden Budstikke, som har kommet ut med tre nummer per år siden. Vi tør påstå at dette er Norges mest proffe hyttemagasin. At han selv skrev mye av innholdet i tillegg til artikler om Jotunheimen i avisen Valdres, sier noe om hans enorme arbeidskapasitet.

På Birgers initiativ har vi hatt gleden av å treffes en langhelg i fjellet - med ektefeller og barn - med uregelmessige mellomrom siden studietiden.

Midt opp i travelheten hadde Birger alltid tid til å reflektere over livet generelt, og legelivet spesielt, sammen med oss. Han var en entusiast som beriket våre liv og som vi alltid kommer til å savne.

Våre tanker går til Anita, barn og barnebarn.

Publisert: 16. august 2021. Tidsskr Nor Legeforen. DOI: 10.4045/tidsskr.21.0458

(C) Tidsskrift for Den norske legeforening 2023. Lastet ned fra tidsskriftet.no 26. april 2023. 